\title{
The association of Familial Mediterranean Fever and cryptogenic
} cirrhosis

\author{
E Baskin*, F Ozcay, US Bayrakci, F Ozbay Hosnut and KS Gulleroglu
}

Address: Baskent University, Ankara, Turkey

* Corresponding author

from $15^{\text {th }}$ Paediatric Rheumatology European Society (PreS) Congress

London, UK. 14-17 September 2008

Published: 15 September 2008

Pediatric Rheumatology 2008, 6(Suppl I):P205 doi:I0.II86/I546-0096-6-SI-P205

This abstract is available from: http://www.ped-rheum.com/content/6/SI/P205

(C) 2008 Baskin et al; licensee BioMed Central Ltd.

Familial Mediaterranian Fever (FMF) is an ethnically related genetic disease, characterized by spontaneously resolving episodes of fever and pain. Amyloidosis of the amyloid A type is the most important manifestation of FMF, affecting many organs, including the kidneys, adrenal glands, intestines, spleen, thyroid, heart, lungs and liver. There is an increasing concern about the association of non-amyloid chronic liver disease and FMF.

We present a 9 year-old male patient from consangious parents who had episodes of recurrent diarrhea, fever, vomiting and abdominal pain since 6 month-old. He was found to have hepatosplenomegaly on his physical examination. Liver biopsy revealed the diagnosis of cryptogenic cirrhosis without any deposition of amyloid. He was also found to have homozygous M694V gene mutation and colchicine was started while he was 7 year-old.

The relation of cryptogenic cirrhosis and FMF is still obscure. Non-amyloid liver disease could be found in patients with FMF as a coincidental finding or as an association and patients with cryptogenic cirrhosis should be investigated for the presence of FMF. 